\title{
Analisis Kapasitas Penampang Sungai Batang Mahat Terhadap Besaran Debit Banjir Menggunakan Pendekatan Model Matematik
}

\author{
Dalrino1), Sadtim²), Hartati³), Indra Agus4) \\ 1), 2), 3), 4) Jurusan Teknik Sipil Politeknik Negeri Padang, Kampus Politeknik Limau Manis Padang \\ email :dalrino350@gmail.com,sadtim@yahoo.co.id,tatiana@yahoo.co.id,indra_daguchi@yahoo.co.id
}

\begin{abstract}
Batang Mahat watershed has a total area of $772.87 \mathrm{~km}^{2}$ with a total length of the main rivers around $44.06 \mathrm{~km}$. With the topographic condition on the upstream side was a mountainous terrain and steep slope relatively into downstream. The problem was can be classified as river siltation, narrowing of the river, and riverbank erosion that has caused flood and threaten a public facilities. Numerical simulations using the application of the HEC RAS model were conducted to determine the capability of the river storage capacity into various discharge values. The results of the analysis show that with the discharge condition Q2 there has been flood caused by the high surface elevation of water that was overtopping of the left and right embankments elevation at the upstream and midstream areas. The water surface elevation will increase with the increasing of flood discharge. River normalization efforts with additional depth and widening of river channel were recommended.
\end{abstract}

Key words: Batang Mahat river, Flood, HEC RAS

\section{PENDAHULUAN}

DAS Batang Mahat memiliki luas total $772.87 \mathrm{~km}^{2}$ dengan total panjang sungai-sungai utama sekitar 44,06 km. Kondisi topografi DAS Sungai Batang Mahat disisi bagian hulu merupakan dataran bergunung dengan kemiringan yang relatif terjal ke arah hilir. (Peta Rupa Bumi Skala 1:50.000, Bakosurtanal). Sebagian besar DAS Sungai Batang Mahat berada di sekitar kawasan budidaya pertanian dan kawasan hutan.Saat ini disepanjang lokasi Sungai Batang Mahat mengalami erosi/abrasi di beberapa tempat, dan terjadi sedimentasi ditempat yang lainnya. Erosi tebing sungai ini menyebabkan beberapa lokasi pemukiman mengalami kemunduran yang mengancam lokasi fasilitas umum. Secara umum, identifikasi pemasalahan yang dihadapi oleh Sungai Batang Mahat dapat diklasifikasikan atas pendangkalan sungai, penyempitan alur, dan erosi tebing sungai yang telah menyebabkan beberapa lokasi pemukiman mengalami kemunduran dan mengancam lokasi fasilitas umum. (Balai Wilayah Sungai Sumatera III, 2012). Untuk mendapatkan gambaran mengenai pola aliran dan potensi genangan yang terjadi atas berbagai besaran debit pada kondisi eksisting dibutuhkan simulasi berupa pemodelan dengan melakukan pendekatan atas proses - proses yang berlaku pada aliran di badan sungai Batang Mahat tersebut. Model pendekatan numerikdigunakan dengan mengaplikasikan paket program komputer HEC-RAS.

\section{TINJAUAN PUSTAKA DAN DASAR TEORI}

Model hidrodinamik HEC-RAS dan SIG telah diaplikasikan untuk mengetahui hidrograf dan kapasitas tampang (bankfull capacity) sungai pada penyebab banjir pada DAS Air Bengkulu. (Tunas, I. G., 2004). Hasil simulasi menunjukkan kapasitas tampang sungai telah terlampaui oleh debit dengan kala ulang 5 tahun dengan terlampauinya elevasi bangunan pengendali banjir eksisting untuk debit dengan kala ulang diatas 5 tahun. Aplikasi HEC-RAS versi 4.1. diterapkan pada studi kapasitas maksimum Sungai Kecepak dengan menggunakan scenario normalisasi pada anak - anak sungainya. Hasil 
simulasi memperlihatkan, normalisasi sungai yang dilakukan telah menempatkan elevasi bantaran eksisting berada diatas profil muka air dari debit rencana dengan tinggi jagaan yang masih memenuhi standard(Arfida Hesa Penta.M., 2016).Simulasi numerik menggunakan aplikasi model HEC RAS juga telah dilakukan untuk penentuan desain peningkatan kapasitas sungai Way Besai, Lampung. Hasil yang didapatkan menunjukkan bahwa tindakan normalisasi mampu memberikan peningkatan kapasitas sebesar $28,6 \%$ dari kondisi eksisting. (Tri Utami , 2016). Studi analisis banjir dengan mempertimbangkan potensi debit rencana akibat perubahan DAS terhadap kapasitas tampang eksisting pada sub DAS Cisimeut Hilir, Banten telah dilakukan dengan menerapkan simulasi menggunakan HEC-RAS 4.1. Hasil simulasi memperlihatkan bahwa Sub-DAS Cisimeut tidak dapat menampung debit aliran yang terjadi, sehingga diperlukan normalisasi sungai, atau alternatif lainnya agar aliran dapat ditampung oleh sungai Cisimeut ( Restu Wigati, R. et al., 2016). Tinjauan penelusuran banjir sebagai akibat pengaruh dari backwater dengan memodelkan aliran tak seragam (unsteasy flow) menggunakanperangkat lunak HECRASmenunjukkan adanya pengaruh back water (air balik) terhadap banjir Sungai Rangkui, kota Pangkalpinang. Hasil penelitian menunjukkan dengan debit rencana pada periode ulang 2, 5, 10 dan 25 tahun, terjadi kenaikan muka air banjir berkisar antara 0.15-1.4 m untuk kondisi tanpa pasang surut dan 0.60-1.90 m untuk kondisi dengan pengaruh pasang surut.(Tia Anandhita , 2015). Penyempitan badan sungai dan alur akibat pendangkalan sebagai dampak tingginya laju sedimentasi sangat berpotensi menyebabkan terjadinya banjir. Pemodelan numerik hidrodinamika aliran di mulut muara yang mengakibatkan banjir telah dilakukan pada muara Sungai Batang Air Dingin. Hasil simulasi menunjukkan terjadinya penyempitan alur akibat sedimentasi oleh pengaruh arus di garis pantai mempengaruhi terjadinya peningkatan potensi banjir (Dalrino, 2018). Program HEC RAS juga telah diaplikasikan dalam simulasi terjadinya banjir akibat perubahan pola arus sebagai implikasi dari tindakan rekayasa pelurusan sungai (sudetan) kearah muara pada kasus Sungai Batang Kandis, Padang Pariaman. Hasil simulasi kemudian digunakan untuk memberikan rekomendasi penanganan banjir (Junaidi et al., 2018). Laju sedimentasi yang cukup besar di hulu di Sungai Batang Mahat akibat pengaruh perubahan tata guna lahan juga terindikasi sangat berpotensi mengakibatkan terjadinya pendangkalan sungai yang selanjutnya dapat berdampak pada terjadinya banjir. (Herdianto, R., 2018).
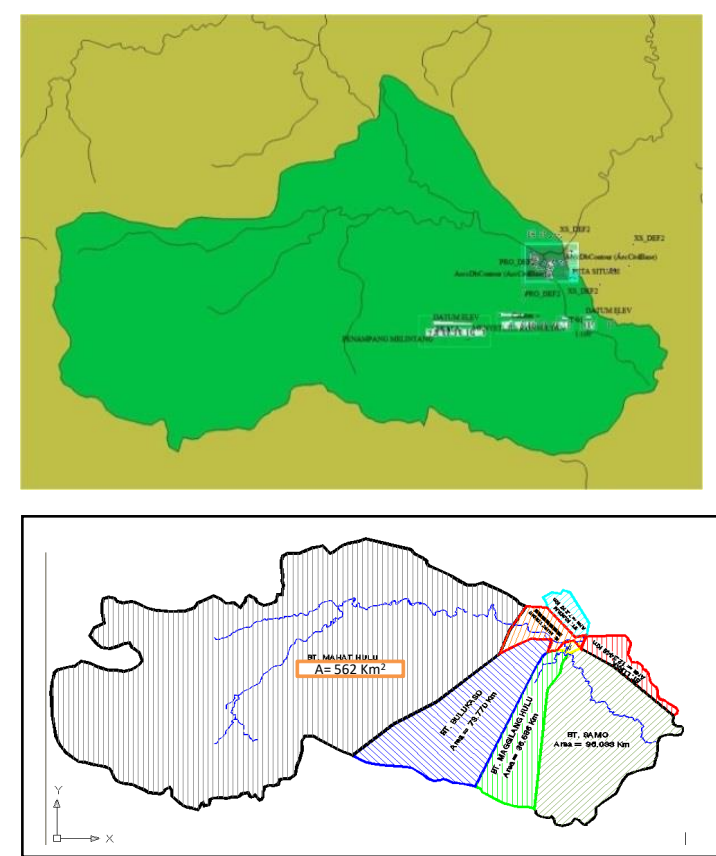

Gambar 1. DAS dan SubDAS Batang Mahat

Untuk mengetahui akibat yang timbul saat debit sungai meningkat akibat curah hujan yang tinggi, maka perlu dilakukan analisa terhadap kapasitas 
debit yang dapat ditampung oleh sungai eksisting serta optimalisasi penampang sungai terhadap debit banjir rencana. Untuk itu diperlukan suatu model pendekatan yang dapat mewakili permasalahan yang sedang dihadapi semirip mungkin. Model pendekatan ini dapat berupa model numerik/matematik atau model fisik.

Pada studi ini digunakan model numerik untuk menyelesaikan permasalahan hidrolik. Meski hasil outputnya tidak seakurat jika digunakan model fisik tetapi model numerik memiliki keunggulan dalam hal penghematan waktu, biaya dan tenaga. Model pendekatan numerik/matematik yang digunakan berupa paket program komputer HEC-RAS yang dibuat dan dikembangkan oleh Hydraulic Engineering Center, salah satu divisi dari the Institute for Water Resources (IWR), U.S. Army Corps of Engineer. Program ini merupakan salah satu bagian dari pengembangan Next Generation (NextGen) dari software Hydrologic Engineering. HEC-RAS pada intinya terdiri dari 3 (tiga) komponen analisa hidraulik 1 (satu) dimensi (one dimensional computation) yaitu :

- Simulasi aliran langgeng satu dimensi (one dimensional steady flow).

- Simulasi aliran tidak langgeng satu dimensi (one dimensional unsteady flow)

- Perhitungan pengangkutan pergerakan sediment.

Pada studi ini, pemodelan hidrolika yang akan dilakukan adalah simulasi aliran langgeng satu dimensi (one dimensional steady flow).

Profil permukaan air dihitung dari suatu potongan melintang saluran ke potongan selanjutnya dengan memecahkan persamaan kekekalan energi dengan prosedur interaktif yang disebut Metode Tahapan Standar (Standard Step
Method). Persamaan kekekalan energi ditulis sebagai berikut:

$$
\mathrm{Y}_{2}+\mathrm{Z}_{2}+\frac{\alpha_{2} \mathrm{~V}_{2}^{2}}{2 \mathrm{~g}}=\mathrm{Y}_{1}+\mathrm{Z}_{1}+\frac{\alpha_{1} \mathrm{~V}_{1}^{2}}{2 \mathrm{~g}}+\mathrm{h}_{\mathrm{e}}
$$

dimana:

$\mathrm{Y}_{1}, \mathrm{Y}_{2}=$ kedalaman air pada potongan melintang

$Z_{1}, Z_{2}=$ elevasi pada saluran utama

$\mathrm{V}_{1}, \mathrm{~V}_{2}=$ kecepatan rata-rata (jumlah total debit)

$\alpha_{1}, \alpha_{2}=$ koefisien tinggi kecepatan

$\mathrm{h}_{\mathrm{e}} \quad=$ kehilangan energi

Kehilangan energi antara dua potongan melintang diakibatkan oleh kehilangan energi akibat gesekan dan ekspansi maupun kontraksi. Persamaan kehilangan tinggi energi dituliskan sebagai berikut:

$$
\mathrm{h}_{\mathrm{e}}=\mathrm{L} \overline{\mathrm{S}}_{\mathrm{f}}+\mathrm{C}\left[\frac{\alpha_{2} \mathrm{~V}_{2}{ }^{2}}{2 \mathrm{~g}}-\frac{\alpha_{1} \mathrm{~V}_{1}^{2}}{2 \mathrm{~g}}\right]
$$

Dengan $L$ adalah jarak sepanjang bentang yang ditinjau, $\bar{S}_{f}$ merupakan kemiringan gesekan (friction slope) antara dua potongan melintang, C adalah koefisien ekspansi atau kontraksi.

Jarak sepanjang bentang yang ditinjau, L, dihitung dengan persamaan:

$\mathrm{L}=\frac{\mathrm{L}_{\text {lob }} \overline{\mathrm{Q}}_{\text {lob }}+\mathrm{L}_{\mathrm{ch}} \overline{\mathrm{Q}}_{\mathrm{ch}}+\mathrm{L}_{\mathrm{rob}} \overline{\mathrm{Q}}_{\text {rob }}}{\overline{\mathrm{Q}}_{\text {lob }}+\overline{\mathrm{Q}}_{\mathrm{ch}}+\overline{\mathrm{Q}}_{\mathrm{rob}}}$

Dimana $L_{\text {lob }}, L_{c h}$, L rob adalah jarak sepanjang potongan melintang pada aliran yang ditinjau di pinggir kiri sungai/left overbank (lob), saluran utama/main channel (ch), dan pinggir kanan sungai/right overbank (rob) dan $\bar{Q}_{\text {lob, }} \bar{Q}_{\text {ch, }} \bar{Q}_{\text {rob }}$ merupakan jarak sepanjang potongan melintang pada aliran yang ditinjau di pinggir kiri sungai (lob), saluran utama (ch), dan pinggir kanan sungai (rob). 
Penentuan penyaluran total aliran dan koefisien kecepatan untuk potongan melintang membutuhkan pembagian aliran menjadi beberapa satuan sehingga kecepatan didistribusikan secara merata. Pendekatan yang digunakan pada HEC - RAS adalah membagi daerah aliran pada pinggir saluran atau sungai dengan menggunakan masukan nilai $\mathrm{n}$ pada potongan melintang dimana nilai $\mathrm{n}$ berubah sebagai dasar pembagian. Penyaluran/aliran dihitung di dalam tiap sub bagian dari bentuk persamaan Manning berikut ini:

$\mathrm{Q}=\mathrm{KS}_{\mathrm{f}}{ }^{1 / 2} ; \mathrm{K}=\frac{1,486}{\mathrm{n}} \mathrm{AR}^{2 / 3}$

Dengan $\mathrm{K}$ adalah penyaluran untuk suatu sub bagian, $\mathrm{n}$ merupakan koefisien kekasaran Manning untuk sub bagian, $A$ adalah luas daerah aliran pada sub bagian dan $R$ merupakan jari-jari hidraulik pada sub bagian. Program akan menjumlahkan tambahan penyaluran pada pinggir saluran utuk mendapatkan penyaluran pada sebelah kiri dan kanan pinggir sungai. Penyaluran saluran utama dihitung dengan cara biasa sebagai satu bagian penyaluran. Jumlah total penyaluran dapat diperoleh dengan menjumlahkan tiga sub bagian penyaluran, yaitu sub bagian kiri pinggir sungai, saluran utama, dan sub bagian kanan pinggir sungai.

Perangkat lunak HEC-RAS adalah program perhitungan profil permukaan air satu dimensi, oleh karenanya hanya satu permukaan air dan satu tinggi energi rata-rata yang dihitung pada tiap potongan melintang. Jika suatu nilai permukaan air diketahui, rata-rata tinggi energi didapatkan dengan menghitung tinggi energi aliran dari tiga sub bagian pada potongan melintang (left overbank, main channel, dan right overbank). Untuk menghitung rata-rata energi kinetik diperlukan perhitungan koefisien tinggi kecepatan alpa $(\alpha)$. Alpha dihitung dengan cara sebagai berikut :

$\alpha \frac{\bar{V}^{2}}{2 \mathrm{~g}}=\frac{\mathrm{Q}_{1}\left(\frac{\mathrm{V}_{1}^{2}}{2 \mathrm{~g}}\right)+\mathrm{Q}_{2}\left(\frac{\mathrm{V}_{2}^{2}}{2 \mathrm{~g}}\right)}{\mathrm{Q}_{1}+\mathrm{Q}_{2}}$

$\alpha=\frac{2 \mathrm{~g}\left[\mathrm{Q}_{1}\left(\frac{\mathrm{V}_{1}^{2}}{2 \mathrm{~g}}\right)+\mathrm{Q}_{2}\left(\frac{\mathrm{V}_{2}{ }^{2}}{2 \mathrm{~g}}\right)\right]}{\left(\mathrm{Q}_{1}+\mathrm{Q}_{2}\right) \overline{\mathrm{V}}^{2}}$

$\alpha=\frac{\mathrm{Q}_{1} \mathrm{~V}_{1}^{2}+\mathrm{Q}_{2} \mathrm{~V}_{1}^{2}}{\left(\mathrm{Q}_{1}+\mathrm{Q}_{2}\right) \overline{\mathrm{V}}^{2}}$

Dalam bentuk umumnya:

$\alpha=\frac{\mathrm{Q}_{1} \mathrm{~V}_{1}^{2}+\mathrm{Q}_{2} \mathrm{~V}_{1}^{2}+\ldots \ldots+\mathrm{Q}_{\mathrm{N}} \mathrm{V}_{\mathrm{N}}^{2}}{\mathrm{QV}^{2}}$

Koefisien kecepatan, $\alpha$, dihitung berdasarkan pada penyaluran di tiga bagian aliran. Persamaan tersebut dapat ditulis dalam bentuk penyaluran dan daerah luasannya seperti pada persamaan di bawah ini:

$\alpha=\frac{\left(\mathrm{A}_{\mathrm{t}}\right)^{2}\left[\frac{\left(\mathrm{K}_{\mathrm{lob}}\right)^{3}}{\left(\mathrm{~A}_{\mathrm{lob}}\right)^{2}}+\frac{\left(\mathrm{K}_{\mathrm{ch}}\right)^{3}}{\left(\mathrm{~A}_{\mathrm{ch}}\right)^{2}}+\frac{\left(\mathrm{K}_{\mathrm{rob}}\right)^{3}}{\left(\mathrm{~A}_{\mathrm{rob}}\right)^{2}}\right]}{\left(\mathrm{K}_{\mathrm{t}}\right)^{3}}$

dengan $A_{t}$ merupakan jumlah total luas daerah aliran pada potongan melintang ; $A_{l o b}, A_{c h}, A_{r o b}$ adalah luas daerah pada tiap sub bagian penampang saluran ; $\mathrm{K}_{\mathrm{t}}$ adalah jumlah total penyaluran pada potongan melintang dan $\mathrm{K}_{\mathrm{lob}}$, $\mathrm{K}_{\mathrm{ch}}$, $\mathrm{K}_{\text {rob }}$ merupakan penyaluran pada sub bagian penampang saluran.

Kehilangan energi akibat gesekan yang diperhitungkan pada HEC-RAS adalah produk dari $S_{f}$ dan L. Kemiringan gesekan Sf pada tiap bagian potongan melintang dihitung dari persamaan Manning sebagai berikut:

$\mathrm{S}_{\mathrm{f}}=\left(\frac{\mathrm{Q}}{\mathrm{K}}\right)^{2}$

Bentuk alternatif persamaan-persamaan kemiringan $S_{f}$ pada HEC-RAS adalah: 
- Persamaan Penyaluran Rata-rata:

$\overline{\mathrm{S}}_{\mathrm{f}}=\left(\frac{\mathrm{Q}_{1}+\mathrm{Q}_{2}}{\mathrm{~K}_{1}+\mathrm{K}_{2}}\right)^{2}$

- Persamaan Kemiringan Gesekan Rata-rata:

$\bar{S}_{\mathrm{f}}=\frac{\mathrm{S}_{\mathrm{f} 1}+\mathrm{S}_{\mathrm{f} 2}}{2}$

- Persamaan Kemiringan Gesekan Rata-rata Geometri:

$\overline{\mathrm{S}}_{\mathrm{f}}=\sqrt{\mathrm{S}_{\mathrm{f} 1} \cdot \mathrm{S}_{\mathrm{f} 2}}$

- Persamaan Kemiringan Gesekan Rata-rata Harmonik:

$\bar{S}_{\mathrm{f}}=\frac{2 \mathrm{~S}_{\mathrm{f} 1} \cdot \mathrm{S}_{\mathrm{f} 2}}{\mathrm{~S}_{\mathrm{f} 1}+\mathrm{S}_{\mathrm{f} 2}}$

Persamaan tersebut diatas adalah persamaan standar yang digunakan oleh program. Persamaan ini secara otomatis digunakan kecuali jika persamaan yang berbeda diinginkan. Program juga menyediakan pilihan untuk memilih persamaan secara otomatis sesuai dengan daerah aliran dan tipe profil yang ditinjau.

Kehilangan energi akibat kontraksi dan ekspansi pada HEC-RAS dihitung dengan persamaan berikut ini:

$h_{\mathrm{o}}=\mathrm{C}\left[\frac{\alpha_{1} \mathrm{~V}_{1}^{2}}{2 \mathrm{~g}}-\frac{\alpha_{2} \mathrm{~V}_{2}^{2}}{2 \mathrm{~g}}\right]$

dimana: $\mathrm{C}=$ koefisien ekspansi atau kontraksi

Program akan mengasumsikan kontraksi terjadi jika tinggi kecepatan di hilir lebih besar dari pada tinggi kecepatan di hulu. Sebaliknya, ekspansi terjadi jika tinggi kecepatan di hulu lebih besar dari pada tinggi kecepatan di hilir.

\section{METODOLOGI}

\section{Skematisasi Jaringan Sungai}

Dalam penelusuran banjir pada aliran tidak permanen, dengan sistem jaringan sungai dengan anak-anak sungainya harus disimulasikan / dihitung secara satu kesatuan sistem jaringan sungai. Analisis ini dimaksudkan untuk mengetahui pengaruh banjir pada sungai dan sistem secara utuh. Tipikal skema jaringan sungai yang dimodelkan dapat dilihat pada gambar dibawah ini. Dalam perencanaan ini, sebelum simulasi perambatan banjir dilakukan perlu dilakukan sungai yang akan dimodelkan dapat dibagi menjadi suatu sistem yang terdiri dan ruas dan titik. Dalam perencanaan ini yang dimodelkan adalah jaringan Sungai Batang Mahat, seperti ditunjukan pada Gambar 3. Dalam model HEC-RAS jaringan Sungai Batang Mahat tersebut disimpan dalam file Geometri.

\section{Penampang Melintang Sungai}

Pada penelusuran banjir diperlukan data tampang sungai berdasarkan hasil pengukuran topografi. Data tampang sungai mempunyai jarak antar ruas $20 \mathrm{~m}$ atau disesuaikan dengan ketelitian yang diperlukan. Kemiringan Dasar sungai rerata ditentukan berdasarkan perbedaan elevasi dasar sungai antar tampang. Panjang sungai yang dimodelkan sepanjang daerah yang akan dilakukan perencanaan detail. Dalam perencanaan ini, setelah skematisasi alur sungai dilakukan. Data Cross-Section masing-masing ruas sungai dimasukan. 


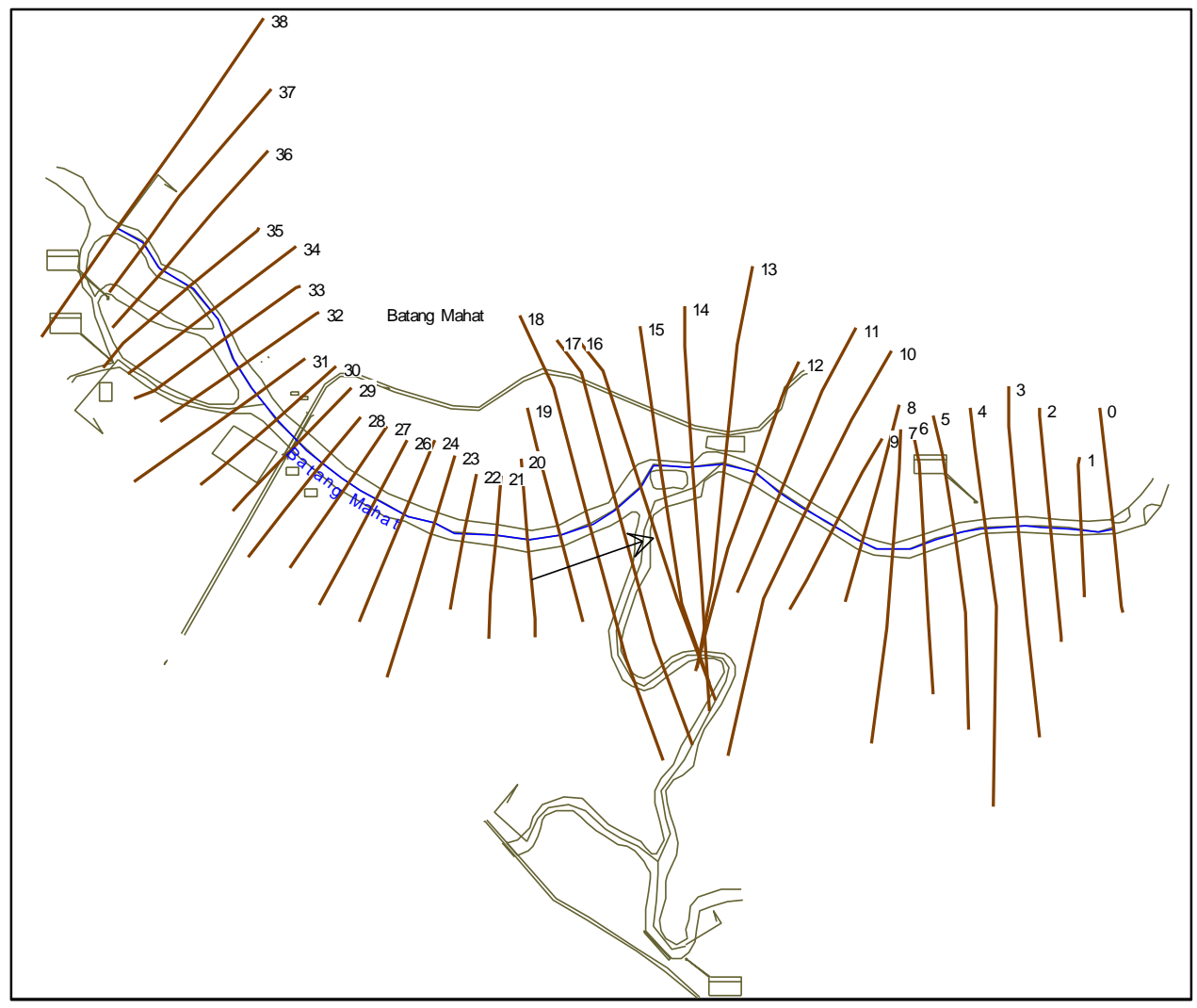

Gambar 2. Model Geometri HEC-RAS Sungai Batang Mahat

\section{Koefisien Kekasaran Dinding}

Besarnya nilai kekasaran dinding dapat didekati dengan pengamatan-pengamatan secara visual pada alur sungai baik pada bagian hulu, bagian tengah dan bagian hilir dari alur sungai yang dimodelkan. Untuk menyederhanakan perhitungan maka nilai koefisien kekasaran manning akibat dari berbagai pengaruh tersebut ditentukan dengan nilai yang tetap baik pada setiap tampang maupun setiap pias/penggal sungai. Dalam perencanaan ini koeffisien kekasaran Manning yang digunakan adalah $\mathrm{n}=0.025$ untuk alur sungai utama dan $n=0.033$ untuk bantaran sungai.

\section{Harga Awal dan Syarat Batas}

Input data yang digunakan sebagai kondisi batas udik adalah hasil perhitungan debit banjir rencana seperti telah diuraikan pada bab sebelumnya. Dalam perencanaan ini profil muka air sungai hanya ditinjau terhadap satu debit rancangan yaitu debit dengan periode ulang 2,5 dan 50 tahun.

Ada tiga macam kondisi yang harus dipenuhi dalam penyelesaian model matematik yaitu kondisi awal, kondisi batas hulu dan kondisi batas hilir. Ketiga kondisi batas tersebut harus ditentukan agar program dapat berjalan (running).

1) Kondisi awal berupa debit aliran sungai yang ditinjau. Kondisi awal ditentukan berdasarkan kondisi awal dengan debit konstan dan tinggi muka air dihitung dengan aliran yang permanen atau dengan memasukan debit base flow sungai untuk sembarang waktu dan titik tinjau.

2) Kondisi batas hulu ditentukan dengan catatan hidrograf banjir rancangan sebagai inflow aliran sungai yang dimodelkan. 
3) Inflow berupa debit Q-2,Q5 dan Q-50 hasil dari Hitungan Hidrologi

\section{HASIL DAN PEMBAHASAN}

\section{Curah Hujan}

Data curah hujan didapatkan dari empat stasiun curah hujan yaitu Stasiun Tanjung Pati-1, Suliki-1, Tanjung Pati-2 dan Suliki-2. Data ini selanjutnya akan digunakan untuk perhitungan debit banjir rencana dengan periode ulang 5, 10, 20, 50 dan 100 tahun

Resume dari hasil perhitungan curah hujan rencana dengan ke tiga metoda tersebut dapat dilihat pada Tabel. 1.

\section{Curah Hujan Wilayah}

Untuk memperoleh besaran hujan maksimum yang dapat dianggap sebagai kedalaman hujan yang sebenarnya terjadi diseluruh DAS, diperoleh pada sejumlah stasiun hujan yang ditempatkan sedemikian rupa sehingga didapatkan besaran hujan di DAS tersebut.

Pengukuran yang dilakukan pada suatu stasiun curah hujan sesungguhnya hanya memperoleh data hujan maksimum yang terjadi pada satu tempat saja. Untuk mendapatkan nilai hujan ratarata pada DAS (Catchment Area) dilakukan dengan menggunakan metode distribusi teoritis Gumbel, Normal dan Log Normal sebagaimana diperlihatkan pada Tabel 2.

\section{Debit Banjir Rencana}

Penentuan debit banjir rencana yang umum digunakan merupakan transformasi dari data curah hujan. Hal ini dimaksudkan untuk perhitungan elevasi tanggul penutup daerah genangan. Besaran debit banjir rencana diprediksi menggunakan perioda ulang 2, 5, 10, 25, 50 dan 100 tahun. Debit banjir rencana ditentukan menggunakan metode Haspers, Weduwen, Unith Hydrograf dan aplikasi Hec HMS diperlihatkan pada Tabel 4.Hidrograf banjir untuk sungai Batang Mahat dengan perioda ulang 25 tahun dapat dilihat pada Gambar 2.

\section{Hasil Simulasi Model Satu DimensiSungai Eksisting}

Profil muka air pada Sungai Batang Mahat dapat ditentukan berdasarkan perhitungan penelusuran banjir menggunakan model HECRAS diatas. Profil muka air ini berisi informasi tentang elevasi tinggi muka air banjir, elevasi dasar sungai, elevasi tebing kiri dan kanan pada ruas sungai yang dimodelkan. Profil ini bertujuan untuk mengetahui cukup tidaknya dimensi saluran yang dicirikan dengan tinggi muka air banjir yang akhirnya menentukan dan elevasi tanggul dan kedalaman galian. Hasil pemodelan numerik bertujuan untuk memprediksi dampak negatif yang mungkin timbul akibat penanggulangan yang akan diterapkan di sistem Sungai Batang Mahat. Selain itu juga hasil pemodelan matematik ini dapat digunakan untuk menentukan muka air rancangan yang didesain pada penanggulangan masalah banjir.

Pada Gambar 4 ditunjukan profil muka air sepanjang Sungai Batang Mahat mulai hulu sampai ke hilir untuk debit Q-2, Q-5 dan Q-50 thn.

Tabel 1. Rekapitulasi Perhitungan Curah Hujan Rencana

\begin{tabular}{|l|c|c|c|c|c|c|}
\hline \multicolumn{1}{|c|}{ Metoda } & $\mathbf{2}$ & $\mathbf{5}$ & $\mathbf{1 0}$ & $\mathbf{2 5}$ & $\mathbf{5 0}$ & $\mathbf{1 0 0}$ \\
\hline GUMBEL & 69.921 & 96.494 & 114.089 & 136.319 & 152.811 & 169.181 \\
\hline NORMAL & 69.677 & 91.040 & 104.713 & 121.557 & 133.850 & 145.963 \\
\hline LOG NORMAL & 68.718 & 88.584 & 102.470 & 120.885 & 135.264 & 150.234 \\
\hline
\end{tabular}


Tabel 2. Perhitungan Curah Hujan Wilayah

\begin{tabular}{|c|c|c|c|c|c|c|c|}
\hline \multirow{2}{*}{ Stasiun } & \multirow{2}{*}{$\begin{array}{c}\text { Luas } \\
\text { Wilayah } \\
\left(\mathrm{km}^{2}\right)\end{array}$} & \multicolumn{6}{|c|}{ Curah Hujan (mm) pada Periode Ulang (Tahun) } \\
\hline & & 2 & 5 & 10 & 25 & 50 & 100 \\
\hline Tanjung Pati-1 & 510.945 & 90.081 & 109.180 & 121.271 & 136.101 & 146.907 & 157.558 \\
\hline Suliki & 294.100 & 68.718 & 88.584 & 102.470 & 120.885 & 135.264 & 150.234 \\
\hline Tanjung Pati & 0.635 & 57.172 & 69.294 & 76.968 & 86.381 & 93.239 & 99.999 \\
\hline Suliki & 0.365 & 25.104 & 32.362 & 37.434 & 44.162 & 49.415 & 54.884 \\
\hline Curah Hujan & & 82.276 & 101.656 & 114.403 & 130.542 & 142.654 & 154.882 \\
\hline
\end{tabular}

Tabel 3. Distribusi Hujan Pola SCS-1A

\begin{tabular}{|c|c|c|c|c|c|c|c|}
\hline \multirow{2}{*}{$\begin{array}{c}\text { Jam } \\
\text { Ke }\end{array}$} & \multirow{2}{*}{$\begin{array}{c}\text { Prob } \\
(\%)\end{array}$} & \multicolumn{6}{|c|}{ Hujan $(\mathrm{mm})$ Tiap Periode Ulang } \\
\hline & & 2 & 5 & 10 & 25 & 50 & 100 \\
\hline 1 & 8.30 & 6.829 & 8.437 & 9.495 & 10.835 & 11.84 & 12.855 \\
\hline 2 & 12.10 & 9.955 & 12.3 & 13.843 & 15.796 & 17.261 & 18.741 \\
\hline 3 & 31.60 & 25.999 & 32.123 & 36.151 & 41.251 & 45.079 & 48.943 \\
\hline 4 & 14.40 & 11.848 & 14.638 & 16.474 & 18.798 & 20. & 22.303 \\
\hline 5 & 10.50 & 8.639 & 10.674 & 12.012 & 13.707 & 14.979 & 16.263 \\
\hline 6 & 8.90 & 7.323 & 9.047 & 10.182 & 11.618 & 12.696 & 13.785 \\
\hline 7 & 7.40 & 6.088 & 7.523 & 8.466 & 9.66 & 10.556 & 11.461 \\
\hline 8 & 6.80 & 5.595 & 6.913 & 7.779 & 8.877 & 9.7 & 10.532 \\
\hline & & 82.276 & 101.655 & 114.402 & 130.542 & 142.653 & 154.883 \\
\hline
\end{tabular}

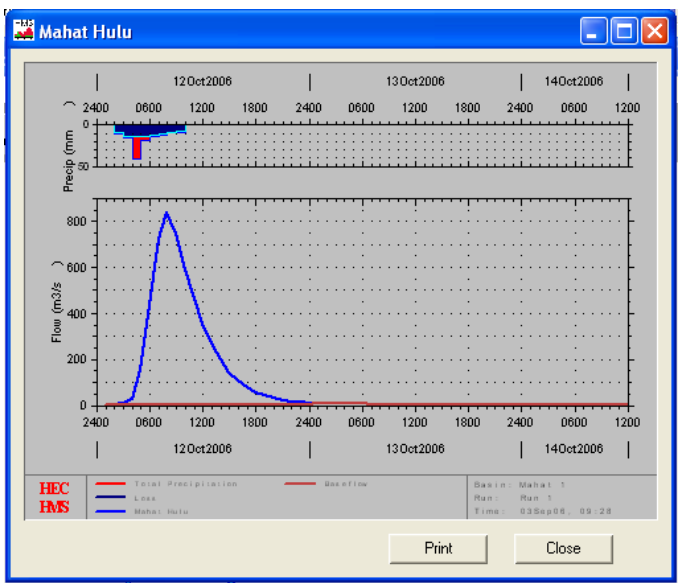

Gambar 3. Hydrograf Banjir di Batang Mahat Hulu Periode Ulang 25 Th (Hasil Output Program HECHMS)

Tabel 4. Rekapitulasi Debit Banjir Rencana Sungai Batang Mahat 1 (M3/dt)

\begin{tabular}{|c|c|c|c|c|c|c|}
\hline \multirow{2}{*}{ SUB DAS } & \multicolumn{6}{|c|}{ DEBIT (m3/dtk) } \\
\hline & 2 & 5 & 10 & 25 & 50 & 100 \\
\hline \multicolumn{7}{|l|}{ BT. BULUKASO } \\
\hline Haspers & 94.253 & 116.070 & 130.334 & 148.308 & 161.738 & 175.250 \\
\hline Weduwen & 36.178 & 47.407 & 55.229 & 65.592 & 73.696 & 82.135 \\
\hline Unith Hydrograf & 110.813 & 136.463 & 153.233 & 174.365 & 190.154 & 206.040 \\
\hline HEC HMS & 58.850 & 83.867 & 105.150 & 135.110 & 159.680 & 186.520 \\
\hline
\end{tabular}




\begin{tabular}{|l|c|c|c|c|c|c|} 
Haspers & 61.314 & 75.507 & 84.786 & 96.479 & 105.215 & 114.006 \\
\hline Weduwen & 17.205 & 22.569 & 26.310 & 31.272 & 35.152 & 39.203 \\
\hline Unith Hydrograf & 54.957 & 67.678 & 75.995 & 86.476 & 94.306 & 102.185 \\
\hline HEC HMS & 29.186 & 41.592 & 52.145 & 67.006 & 79.192 & 92.500 \\
\hline BT. MANGGILANG HILIR & 129.181 & 159.082 & 178.632 & 203.267 & 221.674 & 240.193 \\
\hline Haspers & 66.659 & 87.202 & 101.480 & 120.378 & 135.134 & 150.496 \\
\hline Weduwen & 199.212 & 245.325 & 275.472 & 313.462 & 341.847 & 370.406 \\
\hline Unith Hydrograf & 101.010 & 143.952 & 180.475 & 231.906 & 274.082 & 320.130 \\
\hline HEC HMS & & & & & & \\
\hline BT. SAMO & 108.987 & 134.214 & 150.708 & 171.492 & 187.021 & 202.646 \\
\hline Haspers & 47.527 & 62.239 & 72.477 & 86.035 & 96.629 & 107.663 \\
\hline Weduwen & 144.255 & 177.646 & 199.477 & 226.986 & 247.541 & 268.221 \\
\hline Unith Hydrograf & 71.824 & 102.360 & 128.330 & 164.900 & 194.890 & 227.630 \\
\hline HEC HMS & & & & &
\end{tabular}

\begin{tabular}{|c|c|c|c|c|c|c|}
\hline \multirow{2}{*}{ SUB DAS } & \multicolumn{6}{|c|}{ DEBIT (m3/dtk) } \\
\hline & 2 & 5 & 10 & 25 & 50 & 100 \\
\hline \multicolumn{7}{|l|}{ BT. KASDAM } \\
\hline Haspers & 17.983 & 22.145 & 24.867 & 28.296 & 30.858 & 33.436 \\
\hline Weduwen & 2.827 & 3.703 & 4.313 & 5.123 & 5.756 & 6.417 \\
\hline Unith Hydrograf & 10.830 & 13.337 & 14.976 & 17.042 & 18.585 & 20.138 \\
\hline HEC HMS & 5.752 & 8.197 & 10.277 & 13.205 & 15.607 & 18.229 \\
\hline \multicolumn{7}{|l|}{ BT. LAKUK } \\
\hline Haspers & 27.694 & 34.105 & 38.296 & 43.577 & 47.523 & 51.494 \\
\hline Weduwen & 5.142 & 6.741 & 7.856 & 9.336 & 10.495 & 11.703 \\
\hline Unith Hydrograf & 18.392 & 22.650 & 25.433 & 28.940 & 31.561 & 34.198 \\
\hline HEC HMS & 9.416 & 13.418 & 16.823 & 21.617 & 25.549 & 29.842 \\
\hline \multicolumn{7}{|l|}{ BT. MAHAT HULU } \\
\hline Haspers & 217.999 & 268.460 & 301.451 & 343.025 & 374.086 & 405.339 \\
\hline Weduwen & 230.180 & 299.773 & 347.953 & 411.489 & 460.920 & 512.281 \\
\hline Unith Hydrograf & 683.939 & 842.253 & 945.757 & 1076.183 & 1173.636 & 1271.686 \\
\hline HEC HMS & 363.220 & 517.630 & 648.960 & 833.910 & 985.570 & 1151.200 \\
\hline \multicolumn{7}{|c|}{ BT. MAHAT TENGAH } \\
\hline Haspers & 250.425 & 308.392 & 346.290 & 394.047 & 429.729 & 465.631 \\
\hline Weduwen & 344.036 & 447.504 & 519.045 & 613.316 & 686.582 & 762.660 \\
\hline Unith Hydrograf & 796.391 & 980.734 & 1101.256 & 1253.126 & 1366.602 & 1480.774 \\
\hline HEC HMS & 523.080 & 745.449 & 934.585 & 1200.926 & 1419.332 & 1657.850 \\
\hline \multicolumn{7}{|l|}{ BT. MAHAT HILIR } \\
\hline Haspers & 252.838 & 311.363 & 349.627 & 397.844 & 433.869 & 470.117 \\
\hline Weduwen & 354.228 & 460.719 & 534.378 & 631.369 & 706.794 & 785.069 \\
\hline Unith Hydrograf & 1042.556 & 1283.880 & 1441.655 & 1640.468 & 1789.019 & 1938.482 \\
\hline HEC HMS & 538.248 & 767.064 & 961.685 & 1235.748 & 1460.488 & 1705.921 \\
\hline
\end{tabular}




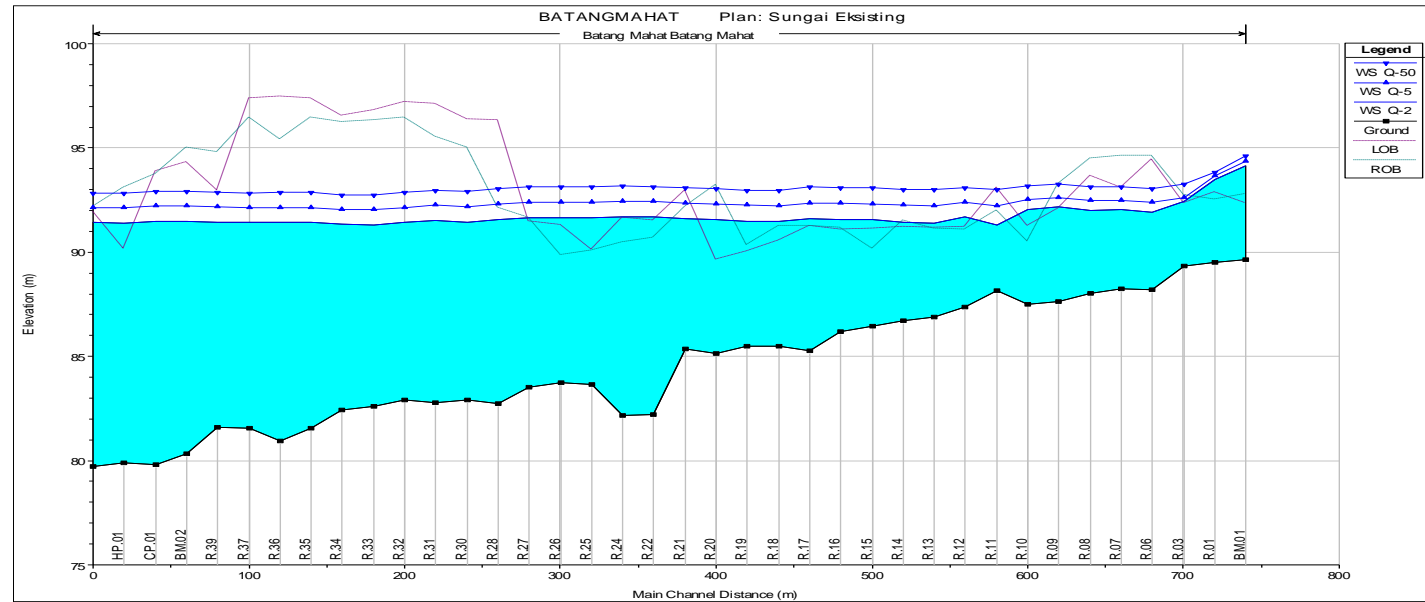

Gambar 4. Penampang Memanjang Sungai Batang Mahat dengan Debit Q-2, Q-5 dan Q-50

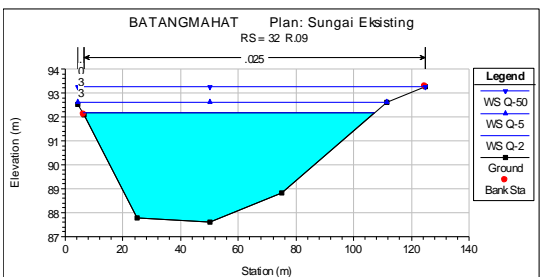

(a). Penampang Aliran di Hulu Batang Mahat

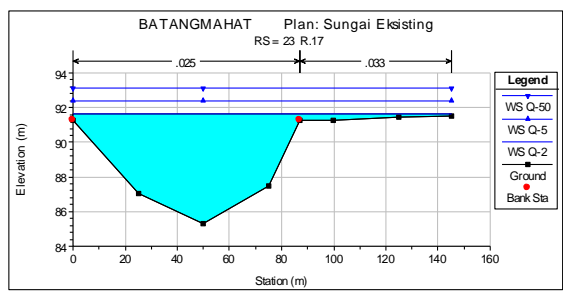

(b). Penampang Aliran pada pertengahan Sungai Batang Mahat

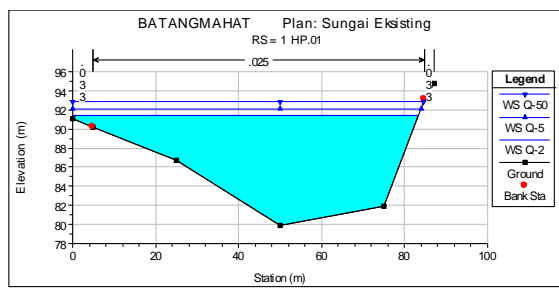

(c). Penampang Aliran pada Hilir Batang Mahat

Gambar 5. Hasil Profil Melintang Sungai dan Muka air pada Q-2, Q-5 dan Q-50 Max

Dari hasil analisis pada kondisi eksisting menunjukkan bahwa dengan kondisi debit rencana Q2 telah terjadi limpasan banjir yang diakibatkan oleh tingginya permukaan air melampauai elevasi tanggul kiri dan kanan saluran sungai di sekitar wilayah hulu dan midstream dari Sungai Batang Mahat. Tinggi permukaan aliran limpasan akan semakin meningkat dengan meningkatnya besaran debit banjir rencana yang digunakan, yaitu Q5 dan
Q50. Dengan melakukan ploting terhadap titik yang digunakan dalam pemodelan terhadap lokasi lapangan, didapatkan kesesuaian bahwa banjir terjadi di sekitar jembatan Pangkalan Koto Baru, serta di sekitar muara anak-anak sungai dari Batang Mahat, yaitu Batang Samo, Batang Manggilang dan Batang Buluh Kasok. 


\section{KESIMPULAN DAN SARAN}

Dari hasil orientasi di lapangan, didapat informasi bahwa lokasi-lokasi banjir disekitar jembatan Pangkalan Koto Baru, serta di sekitar muara anak-anak sungai dari Batang Mahat, yaitu Batang Samo, Batang Manggilang dan Batang Buluh Kasok. Solusi umum yang disarankan adalah dengan melakukan normalisasi penampang sungai dengan bertujuan untuk memperbesar penampang basah aliran. Hal ini dilakukan dengan memberikan pelebaran penampang lebar dasar kearah hulu di Batang Mahat.

Disamping itu penambahan kedalaman aliran dengan melakukan pengerukan di muara-muara anak sungai, yaitu Batang Samo dan Batang Buluh Kasok juga dapat dilakukan untuk menyesuaikan elevasi dasar sungai di Batang Mahat.

\section{DAFTAR PUSTAKA}

Anandhita, T., 2015, Analisis Pengaruh Backwater (Air Balik) Terhadap Banjir Sungai Rangkui Kota Pangkalpinang, Fakultas Teknik Universitas Bangka Belitung, Bangka.

Arfida Hesa Penta.M., 2016, Simulasi Kapasitas Penampang Sungai Dan Profil Muka Air Banjir Dengan Program HEC-RAS Versi 4.1 (Studi Kasus Normalisasi Sungai Kecepak di Kabupaten Banyumas), Univ. Gadjah Mada, Yogyakarta.

Balai Wilayah Sungai Sumatera III, 2012, Laporan SID Pengaman Sungai Batang Mahat

Dalrino, 2018, Wave and Current Hydrodinamics Study at Batang Air Dingin Rivermouth, Padang, Indonesia, International Journal of Civil Engineering and Technology (IJCIET), Vol. 9, Issue 11, Nov. 2018.

Herdianto. R., Istijono,B.,Syofyan, E.R., Dalrino, 2018, Investigation of Pangkalan Floods: Possible Reasons and Future Directions, International Journal on
Advanced Science, Engineering and Information Technology, Vol 8, No 6.

Junaidi, Marona, S., Dalrino, 2018, Simulation of The Effect of Floodway on Batang Kandis River Flood Control, Conference on Innovation in Technology and Engineering Science 2018, Andalas University, Padang

Tri Utami, Purwadi, O.T., Susilo, G.E., 2016, Desain Penampang Sungai Way Besai Melalui Peningkatan Kapasitas Sungai Menggunakan Softwere HEC-RAS, Jurnal Rekayasa Sipil dan Desain, Vol. 4, No. 2, Univ. Lampung, Bandar Lampung.

Tunas, I. G., Yulistiyanto, B., 2004, Model simulasi sistem pengendalian banjir dengan HEC-RAS dan SIG, Master Theses Univ. Gadjah Mada, Yogyakarta

Wigati, R., Sudarsono, Cahyani, I.D., 2016, Analisis Banjir Menggunakan Software HEC-RAS 4.1 (Studi kasus Sub DAS Cisimeut hilir HM 0+00 Sampai dengan HM 69+00), Jurnal Fondasi Vol. 5 No.1, Teknik Sipil Universitas Sultan Ageng Tirtayasa, Serang, Banten. 